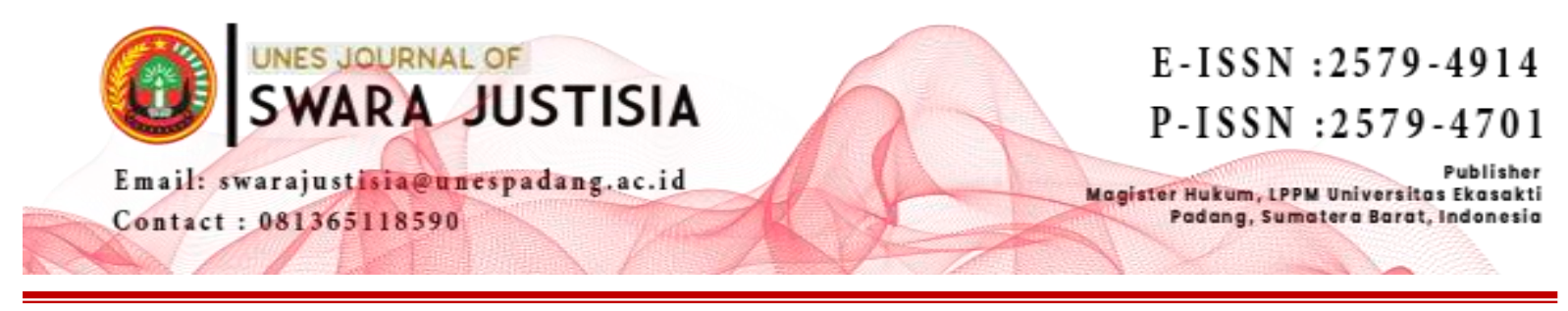

\title{
STRATEGI PENENTUAN LOCUS DELICTI TINDAK PIDANA PENEBANGAN POHON TANPA IZIN DI KAWASAN CAGAR ALAM MANINJAU PADA TINGKAT PENYIDIKAN
}

\author{
Pifzen Finot \\ Program Magister Ilmu Hukum,Universitas Ekasakti, Padang \\ Email: pifzen_ranti84@yahoo.com
}

\begin{abstract}
Efforts to Determine Locus Delicti The crime of cutting down trees without permission in the Maninjau Nature Reserve at the Investigation Stage by the Agam Police Unit is to fulfill the material elements of the criminal law regulations that are violated, namely the prohibited act is logging in the prohibited area as contained in Article 82 paragraph (1) letters $b$ and c. In West Sumatra there is a customary community unit that has power over land known as ulayat land. The location where the felled timber is known as the determination of Locus Delicti in forestry crimes. Constraints in Determining Locus Delicti Timber Theft in the Maninjau Nature Reserve at the Investigation Stage by the Criminal Investigation Unit of the Religious Police is a legal factor in which the Criminal Procedure Code (KUHAP) does not regulate with certainty and clearly the method or theory used to determine locus delicti. a criminal act. Another internal factor is the human factor (law enforcement officers), in this case the Police investigator who does not have special expertise in determining the location of the crime of illegal logging, so it requires expert information. Community members are reluctant to be witnesses.
\end{abstract}

Keywords: Investigation, Crime Printing trees without permission, Locus Delicti

\begin{abstract}
ABSTRAK
Upaya Penetapan Locus Delicti Tindak pidana menebang pohon tanpa izin di Cagar Alam Maninjau pada Tahap Penyidikan oleh Satpol PP Agam adalah untuk memenuhi unsur materiil peraturan perundang-undangan pidana yang dilanggar yaitu perbuatan yang dilarang adalah penebangan kayu di hutan. kawasan terlarang sebagaimana dimaksud dalam Pasal 82 ayat (1) huruf b dan c. Di Sumatera Barat terdapat kesatuan masyarakat adat yang menguasai tanah yang disebut tanah ulayat. Lokasi kayu tebangan tersebut dikenal dengan penetapan Locus Delicti dalam tindak pidana kehutanan. Kendala Penetapan Locus Delicti Pencurian Kayu di Cagar Alam Maninjau Pada Tahap Penyidikan oleh Bareskrim Polri merupakan faktor hukum dimana KUHAP tidak mengatur secara pasti dan jelas metode atau teori yang digunakan untuk menentukan locus delicti. suatu tindakan kriminal. Faktor internal lainnya adalah faktor manusia (aparat penegak hukum), dalam hal ini penyidik Polri yang tidak memiliki keahlian khusus dalam menentukan lokasi tindak pidana illegal logging, sehingga memerlukan keterangan ahli. Anggota masyarakat enggan menjadi saksi.
\end{abstract}

Kata kunci: Penyidikan, Pencetakan Kejahatan Pohon Tanpa Izin, Locus Delicti 


\section{PENDAHULUAN}

Tindak pidana kehutanan diatur dalam Undang undang Nomor 18 Tahun 2013 tentang Pencegahan dan Pemberantasan Perusakan Hutan yang merupakan pembaharuan dari Undang-Undang Nomor 41 Tahun 1999 tentang Kehutanan. Dimana pada undang-undang ini dijelaskan, bahwa perusakan hutan adalah proses, cara, atau perbuatan merusak hutan melalui kegiatan pembalakan liar, penggunaan kawasan hutan tanpa izin. Penebangan liar diatur pada Pasal 82 Undang undang Nomor 18 Tahun 2013 tentang Pencegahan dan Pemberantasan Perusakan Hutan.

Di kabupaten Agam pelanggaran kehutanan yang umum ditemukan oleh penyidik untuk ditangani berdasarkan undang undang diantaranya adalah Pembalakan liar (illegal logging) terjadi karena adanya kerjasama antara masyarakat lokal berperan sebagai pelaksana di lapangan dengan para cukong bertindak sebagai pemodal yang akan membeli kayu-kayu hasil tebangan tersebut, adakalanya cukong tidak hanya menampung dan membeli kayu-kayu hasil tebangan namun juga mensuplai alat-alat berat kepada masyarakat untuk kebutuhan pengangkutan. Untuk mengatasi maraknya tindak pidana pembalakan liar (illegal logging) jajaran aparat penegak hukum dalam hal ini penyidik Polri telah melakukan penegakan hukum dengan cara melaksanakan penyidikan terhadap tindak pidana illegal logging tersebut.

Menurut pendapat Haryadi Kartodiharjo, pembalakan liar (illegal logging) merupakan penebangan kayu secara tidak sah dan melanggar peraturan perundang-undangan, yaitu berupa pencurian kayu didalam kawasan hutan Negara atau hutan hak (milik) dan atau pemegang ijin melakukan penebangan lebih dari jatah yang telah ditetapkan dalam perizinan. ${ }^{1}$ Banyak ditemui kasus dimana orang/warga masyarakat melakukan pembalakan liar (illegal logging) dengan alasan ekonomi melakukan penebangan satu buah pohon kayu dihutan. Adanya berbagai kasus di daerah dimana seseorang karena sekedar memenuhi kebutuhan ekonomi menebang, mengambil dan membawa sebatang kayu dari hutan tanpa ijin pejabat yang berwenang dikenakan tindak pidana pembalakan liar (illegal logging).

Pada Kabupaten Agam terdapat kawasan cagar alam Maninjau yang memiliki kawasan hutan yang cukup luas. Disatu pihak, secara de facto, kawasan-kawasan yang ditetapkan dengan fungsi konservasi berada di wilayah administratif daerah. Orang di tingkat daerah sangat memahami kondisi faktual dan kebutuhan bagi pengolah hutan yang terbaik. Pemerintah daerah selalu berpikir bahwa sumber daya alam tersebut dimanfaatkan secara optimal untuk pembangunan dan kesejahteraan masyarakat daerah. Terhadap tindak pidana illegal logging yang dilakukan selama ini, dirasa masih belum mampu memberikan efek jera bagi pelaku maupun masyarakatnya pada umummya.

Hutan Cagar Alam Maninjau luasnya 21.891,78 hektare dan berada di wilayah Kabupaten Agam dan Padang Pariaman. Sekitar 2.975,42 hektare area cagar alam itu mengalami degradasi akibat pembalakan liar, perambahan, pembangunan permukiman dan jalan, pembukaan lahan pertanian, dan aktivitas non-kehutanan lainnya. Selama tahun 2019 Badan Konservasi Sumber Daya Alam (BKSDA) dan Polres Agam berhasil mengungkap 5 kasus pembalakan liar dan menangkap sepuluh pelaku. Dasar penetapan kawasan Suaka

\footnotetext{
${ }^{1}$ Haryadi Kartodiharjo, Modus Operandi, Scientific Evidence dan Legal Evidence Dalam Kasus Illegal Logging, Makalah disampaikan dalam Pelatihan Hakim Penegakan Hukum Lingkungan yang diselenggarakan oleh ICEL bekerjasama dengan Mahkamah Agung RI, Jakarta 2003
} 
Alam Dan kawasan Pelestarian alam sebagai Cagar Alam Maninjau: Keputusan Menteri Lingkungan Hidup dan Kehutanan Republik Indonesia Nomor SK.598/Menlhk/Setjen/PLA.2/8/2016.

Adapun kasus tindak pidana penebangan pohon tanpa izin yang terjadi pada kawasan cagar alam Maninjau adalah Tim Gabungan Yg terdiri dari Polres Agam dan BKSDA Resor Agam melaksanakan patroli dalam kawasan cagar alam maninjau dan menemukan 4 (empat) orang yang sedang menebang pohon dan keempat org tersebut beserta barang bukti diamankan ke Polres Agam. Setelah dilakukan pemeriksaan terhadap pelapor dan saksi dari pihak BKSDA menyatakan bahwa setelah dilakukan cek koordinat lokasi tersebut termasuk dalam kawasan cagar alam maninjau kemudian penyidik mengambil keterangan dari terlapor dan mereka menyatakan bahwa mereka menerima upah dari pemilik tanah utk melakukan penebangan kayu di lokasi tersebut dan tanah tersebut mempunyai sertifikat hak milik. Setelah dilakukan titik koordinat tanah oleh pihak Badan Pertanahan Nasional (BPN) Kabupaten Agam menjelaskan bahwa lokasi tersebut sesuai dengan sertifikat yg diterbitkan BPN Kabupaten Agam dengan Nomor SHM no 65 tahun 2002. Permasalahan dalam penyidikan adalah pihak BKSDA sesuai dengen cek titik koordinat menyatakan lokasi tersebut termasuk Kawasan Cagar Alam Maninjau sedangkan dari pihak pemilik tanah menyatakan lokasi tersebut milik yang bersangkutan dibuktikan dengan sertifikat hak milik dan juga telah sesuai dengan titik koordinat yang telah dilakukan oleh pihak BPN Kabupaten Agam.

Berdasarkan latar belakang pemikiran yang telah dipaparkan di atas, maka rumusan permasalahan adalah strategi penentuan locus delicti tindak pidana penebangan pohon tanpa izin di kawasan cagar alam Maninjau pada tingkat penyidikan oleh Satreskrim Polres Agam dan kendala dalam penentuan tersebut.

\section{METODE PENELITIAN}

Spesifikasi penelitian adalah deskriptif analitis, dengan metode pendekatan yuridis normative didukung yuridis empiris. Jenis data yang digunakan adalah data sekunder. Data sekunder diperoleh dari studi dokumen dan studi kepustakaan. Data yang diperoleh kemudian dianalisa secara kualitatif .

\section{PEMBAHASAN}

\section{A. Strategi Penentuan Locus Delicti Tindak Pidana Penebangan Pohon Tanpa Izin Di Kawasan Cagar Alam Maninjau Pada Tahap Penyidikan Oleh Satreskrim Polres Agam}

Besarnya kontribusi sektor kehutanan dan industri turunannya dalam menopang perekonomian merupakan salah satu faktor pendukung maraknya illegal logging atau kejahatan pencurian kayu dan penebangan liar. Hal ini sekaligus menjadi masalah tersendiri dalam hal penegakan hukum kasus illegal logging. Kontribusi sektor kehutanan sebagai penopang perekonomian ini bukan hanya dilihat dari sisi masyarakat sebagai pelaku, tetapi dilihat juga oleh daerah sebagai potensi penyumbang Pendapatan Asli 
Daerah (PAD) melalui perusahaan yang mengantongi Ijin Usaha Pemungutan Hasil Hutan Kayu (IUPHHK) yang pada kenyataannya banyak perusahaan melanggar ijin tersebut. ${ }^{2}$

Permasalahan yang sering terjadi di Sumatera barat secara umum dan Kabupaten Agam secara khusus dalam hal pengambilan hasil hutan ini dalah status tanah tempat tumbuhnya kayu tersebut. Di Sumatera Barat atau sering disebut dengan daerah Minangkabau terdapat kesatuan masyarakat adat yang memiliki kekuasaan atas tanah yang dikenal dengan tanah ulayat. Pada tindak pidana pencurian kayu dalam penyidikannya perlu ditentukan secara tepat lokasi atau tempat kayu yang ditebang tersebut berada. Apakah kayu tersebut berada pada kawasan yang dilarang untuk dilakukan penebangan ataukah berada pada lahan milik masyarakat atau masyarakat adat. Lokasi tempat beradanya kayu yang ditebang tersebut dikenal dengan penentuan Locus Delicti pada tindak pidana kehutanan.

Locus dalam Bahasa Inggris yang berarti lokasi atau tempat, secara istilah yaitu berlakunya hukum pidana yang dilihat dari segi lokasi terjadinya perbuatan pidana. Persoalan tentang tempat terjadinya tindak pidana (locus delicti) tidak hanya penting dalam perspektif hukum pidana formil, akan tetapi dalam perspektif hukum pidana pada umumnya. Secara umum kepastian mengenai tempat terjadinya tindak pidana (locus delicti) penting pula terhadap beberapa hal berikut ini: ${ }^{3}$

1. Berkaitan dengan kompetensi relatif dari pengadilan, yaitu menentukan pengadilan negara mana yang berwenang mengadili tindak pidana yang terjadi di suatu tempat tertentu. Kepastian tempat tindak pidana (locus delicti) penting dan perlu diperhitungkan berhubung setiap pengadilan memiliki wilayah yuridiksi yang berbeda satu dengan yang lainnya. Pengadilan hanya dapat menangani atau mengadili kasus yang hanya berada dalam jangkauan wilayah administratif kabupaten/ kota, pengadilan dapat menangani perkara perkara yang diajukan. Dengan demikian, dengan diketahuinya tempat terjadinya tindak pidana (locus delicti) maka, diketahui pula pengadilan mana yang berwenang mengadili terhadap tindak pidana yang terjadi yang berada di wilayah administratifnya (kewenangan relatif).

2. Berkaitan dengan ruang lingkup berlakunya aturan pidana Indonesia sebagaimana yang telah diatur dalam Pasal 2 sampai dengan Pasal 9 KUHP. Dalam ketentuan Pasal 2 KUHP menyatakan, "Bahwa aturan pidana Indonesia berlaku bagi setiap orang (bagi warga negara Indonesia ataupun WNA) yang melakukan perbuatan pidana di Indonesia". Sehingga dengan diketahuinya tempat terjadi tindakan pidana (locus delicti) misalkan terjadi diluar negeri maka aturan pidana tidak berlaku bagi setiap orang kecuali yang diatur dalam Undang Undang. Misalnya hanya berlaku bagi warga negara Indonesia yang melakukan tindakan tertentu saja, sebagaimana yang telah diatur dalam Pasal 5 (1) dan ke 2 KUHP yang menyatakan ; Aturan pidana dalam perundang undangan Indonesia berlaku bagi warga negara Indonesia yang diluar Indonesia melakukan : Ke 2 salah satu perbuatan yang oleh suatu aturan pidana dalam perundang

${ }^{2}$ Lihat Fadli. Moh. Noch, Permasalahan Penegakan Hukum Kejahatan Kehutanan (Illegal logging) di Kalimantan Timur. Web; http://fadlimohnoch.blogspot. com/2011/02/permasalahan-penegakan-hukumkejahatan.html diakses tanggal 5 November 2020

${ }^{3}$ Satochid Kartanegara, Hukum Pidana,: Balai Lektur Mahasiswa, Yogyakarta, 2000, hlm 151 
undangan Indonesia dipandang sebagai kejahatan sedangkan menurut undang undang negara negara dimana perbuatan dilakukan, diancam pidana.

3. Berkaitan dengan pengecualian seperti yang dimaksudkan dalam Pasal 9 KUHP. Berdasarkan ketentuan Pasal 9 KUHP telah ditentukan bahwasanya ketentuan Pasal 2, 5, 7 dan 8 berlakunya dibatasi oleh pengecualian yang telah diakui dalam hukum international. Dengan adanya pembatasan ketentuan Pasal 9 KUHP tersebut dapat diartikan apabila dalam wilayah teritorial terjadi tindak pidana internasional, maka asas teritorial sebagaimana yang ditentukan dalam Pasal 2 KUHP tidak berlaku mutlak. Sebab meskipun tindak pidana yang terjadi berada di wilayah teritorial Indonesia tidak diadili berdasarkan peraturan pidana Indonesia melainkan peraturan negara lain. Hal ini disebabkan karena menurut peraturan pidana internasional setiap negara memiliki kewenangan yang sama terhadap tindak pidana international yang terjadi dimanapun locus delicti dari kejahatan internasional tersebut.

4. Berkaitan dengan adanya syarat, bahwa sebuah tindakan dapat dikatakan perbuatan pidana apabila dilakukan ditempat umum, misalnya suatu tindakan pidana yang menodai nilai nilai kesusilaan di tempat umum seperti yang telah diatur dalam Pasal 281 KUHP. Hal yang berkaitan dengan syarat ini dikatakan suatu perbuatan tindak pidana apabila tidak sesuai tempatnya pelaksanaannya, seperti yang dicontohkan diatas apabila dilakukan dalam tempat tertutup hal itu bukan merupakan tindak pidana namun jika dilakukan ditempat umum meskipun dilakukan oleh pasangan resmi secara hukum, tetap perbuatan tersebut dianggap perbuatan tindak pidana karena dianggap menciderai nilai kesusilaan.

5. Salah satu syarat mutlak sahnya surat dakwaan.

Pada tindak pidana kehutanan perbuatan yang dilarang adalah melakukan penebangan pada kawasan yang dilarang sebagaimana terdapat pada Pasal 82 ayat (1) huruf $b$ dan c. Dimana Unsur utama yang harus terpenuhi adalah Unsur "yang dengan sengaja". Pada kasus yang diteliti Bahwa tersangka telah dengan segaja memasuki kawasan hutan cagar alam Maninjau dengan membawa alat pemotong kayu Sinsaw dan kemudian melakukan penebangan pohon kayu dalam kawasan Hutan cagar Alam Maninjau tanpa memiliki izin yang dikeluarkan oleh penjabat yang berwenang dengan maksud dan tujuan tersangka ingin mendapatkan kayu untuk diolah dan dijual.

Unsur selanjutnya adalah "Melakukan penebangan pohon dalam kawasan hutan tanpa memiliki izin yang dikeluarkan oleh penjabat yang berwenang." Telah terpenuhi dengan penjelasannya sebagai berikut Bahwa tersangka melakukan penebangan kayu dikawasan hutan cagar alam maninjau dengan cara menghidupkan mesin Cinsaw (sinso) dan mengarahkan mata Bar Cinsaw (sinso) pada pangkal pohon yang ditebang, hingga pangkal pohon menjadi putus dan pohon tersebut jatuh tumbang ketanah, setelah itu pohon yang telah tumbang kemudian dipotong lagi dengan ukuran panjang sekira 4 (empat) Meter, setelah itu mengganti rantai pembelah untuk membelah pohon tersebut, dan melanjutkan kegiatan kami membelah kayu yang telah dipotong, dengan memakai 1 (satu) buah gulungan benang penggaris yang diberi gincu, tersangka langsung memberi garisian ukuran pada kayu, setelah itu mulai membelah kayu tersebut dan tersangka membersihkan serbuk bekas aritan kayu yang masih menempal pada kayu yang sedang diolah, dan 
kegiatan menjadi operator Cinsaw tersangka lakukan secara bergantian, perbuatan tersebut tersangka lakukan tanpa memiliki izin dari pejabat yang berwenang.

Selanjutnya Unsur "Melakukan penebangan pohon dalam kawasan hutan secara tidak syah." Telah terpenuhi dengan alat bukti keterangan ahli yang menyatakan bahwa penebangan dilakukan atau tempat terjadinya tindak pidana adalah dalam kawasan cagar alam Maninjau. Penentuan lokasi atau locus delicti ini dilakukan oleh aparat penegak hukum tetap berpegang pada teori yang ada yaitu teori tempat dimana kejahatan dilakukan atau teori perbuatan alat, teori alat yang digunakan dalam melakukan kejahatan, dan teori akibat yang di timbulkan atas delik pidana yang dilakukan oleh pelaku.

Maka dari itu penentuan locus delicti dalam suatu tindak pidana kehutanan berupa penebangan pohon pada kawasan hutan dengan tanpa izin dilakukan berdasarkan dimana perbuatan dan alat yang digunakan untuk melakukan tindak pidana itu terjadi. Penyidik menggunakan dasar dari penerapan teori ini adalah pada keterangan ahli. Ahli mengukur tempat kejadian perkara dengan cara menentukan kawasan cagar alam dengan mengambil titik-titik koordinat tunggul kayu yang telah ditebang yang mana tunggul (1) koordinat : S $00^{\circ} 15^{\prime} 39.6^{\prime \prime} \mathrm{E} 100^{\circ}$. 04' 50.5”, Tunggul (2) koordinat : S $00^{\circ} 15^{\prime} 39,2^{\prime \prime} \mathrm{E}$ $100^{\circ}$ 04' 50.6' Tunggul (3) koordinat: S 00 $15^{\prime}$ '39,3' E 10004'51.1, Tunggul (4) koordinat: S $00^{\circ} 15^{\prime} 39,2^{\prime \prime}$ E $100^{\circ} 04^{\prime} 51.1$ ', Berada di dalam Kawasan Hutan Cagar Alam Maninjau.

Ahli mencek bahwa tunggul (1) koordinat : S $00^{\circ} 15^{\prime} 39.66^{\prime \prime} \mathrm{E} 100^{\circ}$. 04'50.5”, Tunggul (2) koordinat : S $00^{\circ} 15^{\prime} 39,2^{\prime \prime} \mathrm{E} 100^{\circ} 04^{\prime} 50.6^{\prime \prime}$ Tunggul (3) koordinat : S $00^{\circ} 15^{\prime}$ 39,3' E $100^{\circ} 04 ' 51.1$, Tunggul (4) koordinat : S 00¹5'39,2' E 100 04'51.1” dengan menggunakan adalah alat berupa Global Position System (GPS) Merk GARMIN Type MONTANA Seri 680 dan untuk menentukan posisi titik koordinat tunggul kayu yang telah diambil masuk atau tidaknya kedalam Kawasan Hutan Cagar Alam Maninjau, kemudian titik koordinat yang didapat tersebut di Ploting ke dalam aplikasi perpetaan menggunakan perangkat lunak Arcgis 10.1 produk dari ESRI. Dimana titik-titik koordinat tersebut dilayerkan dengan peta lampiran Keputusan Menteri Kehutanan No. SK35/Menhut-II/2013 dan peta lampiran Keputusan Menteri Lingkungan Hidup dan Kehutanan Nomor SK 598/Menlhk/Setjen/PLA.2/8/2016. Dari hasil layer tersebut diketahui ke 4 (empat) titik koordinat tunggul bekas tebangan yang dilakukan oleh $\mathrm{Sdr}$ Nasrul Pgl Anas dan Sdr Susi Suharto Pgl Susi berada di dalam kawasan hutan cagar alam Maninjau.

Ahli menerangkan bahwa Risalah atau kronologis pengukuhan atau penunjukan kawasan cagar alam Maninjau dimulai penetapan sebagai hutan Register 7 pada tahun 1920 melalui Governement Besluit (GB) Nomor 5 tahun 1920 tanggal 05 Januari 1920 oleh Gubernur Belanda pada masa itu, Selanjutnya pada tahun 1982 Menteri Pertanian melalui Keputusan Nomor.623/Kpts/Um/8/1982 tanggal 25 Agustus 1982 menunjuk kawasan hutan Register 7 sebagai hutan suaka alam wisata (HSAW) dengan nama HSAW Maninjau Utara-Selatan itu, Pada tahun 1988-1992 dilaksanakan tata batas sepanjang 230,10 Kilometer dan sudah temu gelang, Pada tahun 1999 melalui Surat Keputusan Menteri Kehutanan dan Perkebunan RI Nomor: 422/Kpts-II/1999 Tanggal 15 Juni 1999 kawasan hutan suaka alam wisata (HSDAW) Maninjau Utara-Selatan mengalami perubahan luas, menjadi 22.206 hektar, Kemudian pada tahun 2013, melalui Surat 
Keputusan Menteri Kehutanan RI Nomor: 35/Menhut-II/2013 Tanggal 15 Januari 2013 Hutan Suaka Alam Wisata (HSAW) Maninjau Utara-Selatan berubah menjadi kawasan suaka alam (KSA) Maninjau dengan luas 21.891,78 hektar, Pada tahun 2016, dengan Surat Keputusan Menteri Lingkungan Hidup dan Kehutanan Nomor.SK 598/Menlhk/Setjen/PLA.2/8/2016 ditetapkan fungsi pokok kawasan suaka alam (KSA) Maninjau menjadi Cagar Alam (CA) Maninjau dengan luas 21.891,78 hektar.

Berdasarkan penentuan locus delicti tersebut maka telah dapat diterapkan hukum pidana materil yaitu Pasal 82 ayat (1) huruf b dan c undang undang kehutanan. Perbuatan utama yang dilarang dalam ketentuan ini adalah melakukan penebangan dalam kawasan hutan termasuk adalah kawasan hutan cagar alam. Sesuai dengan Pasal 17 ayat (1) Undang Undang Nomor 5 tahun 1990 tentang Konservasi Sumber Daya Alam Hayati dan Ekosistemnya di dalam kawasan hutan cagar alam hanya dapat dilakukan kegiatan untuk kepentingan penelitian dan pengembangan, ilmu pengetahuan, pendidikan, dan kegiatan lainnya yang menunjang budidaya. Kawasan hutan dengan fungsi konservasi berbentuk kawasan suaka alam yang salah satunya adalah cagar alam tidak ada atau tidak dapat diberikan izin penebangan kayu sesuai dengan undang undang nomor 5 tahun 1990 tentang konservasi sumber daya alam hayati dan ekosistemnya pasal 15 dan pasal 17. Larangan ini diatur karena penebangan kayu dapat mengakibatkan berkurangnya kemampuan hutan untuk menyediakan oksigen, penyuplai air dan berkurangnya kemampuan untuk mengendalikan erosi yang dapat berakibat fatal pada terjadinya bancana tanah longsor.

Urgensi penentuan locus delicti pada tindak pidana pencurian Kayu adalah untuk memenuhi unsur delik pada Pasal 82 ayat (1) huruf b dan c dimana perbuatan yang dilarang adalah melakukan penebangan kayu pada kawasan hutan yang dilindungi atau dalam cagar alam. Locus delicti ditentukan menurut tunggul kayu yang sudah ditebang. Apabila berada pada kawasan hutan yang dilindungi maka akan terpenuhi unsur perbuatan materil namun apabila berada pada kawasan atau tempat yang bukan daerah kawasan hutan yang dilindungi atau cagar alam maka tidak terpenuhi unsur perbuatan materilnya.

\section{B. Kendala Dalam Penentuan Locus Delicti Tindak Pidana Penebangan Pohon Tanpa Izin Di Kawasan Cagar Alam Maninjau Pada Tahap Penyidikan Oleh Satreskrim Polres Agam}

Faktor internal yang menjadi kendala adalah faktor Manusianya (Aparat penegak hukum) Proses penyelesaian suatu perkara tindak pidana juga perlu ditunjang dengan adanya aparat penegak hukum. Berhasil dengan tidaknya proses penyelesaian proses perkara sangat tergantung pada manusianya. Kurangnya kemampuan teknis dibidang penegak hukum, justru akan menghambat pelaksanaan penegakan hukum. Hal ini sesuai dengan teori bekerjanya hukum yang disampaikan oleh Robert Seidman bahwa terlaksananya suatu aturan perundang undangan atau hukum itu sendiri dipengaruhi oleh cara bekerjanya aparat penegak hukum atau petugas pelaksana hukum tersebut. Sehubungan dengan kurangnya kemampuan dari aparat penegak hukum dalam melaksanakan tugasnya akan membawa dampak negatif.

Faktor sarana dan prasarana Tanpa adanya sarana atau fasilitas yang mendukung, maka tidak mungkin penegakan hukum akan berlangsung dengan lancar. Sebaliknya 
kurangnya sarana dan prasarana yang mendukung pelaksanaan tugas, hasilnya tentu tidak seperti yang diharapkan. Sarana atau fasilitas tersebut antara lain organisasi yang baik, peralatan yang memadai serta keuangan yang cukup. Kalau hal tersebut tidak terpenuhi maka mustahil penegakan hukum akan mencapai tujuan yang maksimal. Ketiadaan sarana dan keahlian bagi apparat penegaka hukum dalam penyidikan tindak pidana kehutanan mengharuskan penyidik untuk menggunakan bantuan keterangan ahli. Proses administrasi permintaan keterangan ahli memerlukan waktu yang cukup lama. Tenaga ahli yang dapat menerangkan tentang titik koordinat tempat terjadinya perkara penebangan kayu secara illegal dengan baik dan pasti tersebut juga sulit bagi kondisi daerah kabupaten Agam yang jauh dari pusat pemerintahan provinsi.

Kurangnya kordinasi dan komunikasi antara penyidik dan penuntut umum. Hasil penyidikan yang belum lengkap yang disebabkan tidak terselenggaranya dengan baik konsultasi antara penyidik dan penuntut umum pada tahap penyidikan atau pra penuntutan. Perbedaan persepsi apa yang diarahkan oleh penuntut umum dengan apa yang dilakukan oleh penyidik akan berpengaruh terhadap berkas perkara hasil penyidikan yang kemudian dikembalikan oleh penuntut umum sehingga dinyatakan masih kurang lengkap atau belum lengkap, sudah barang tentu akan berpengaruh pada nasib penyelesaian perkara pidana.

Faktor eksternal diantaranya faktor Kesadaran hukum masyarakat yang relatif rendah tentunya akan membawa pengaruh negatif terhadap pelaksanaan penegakan hukum yaitu mempengaruhi proses penuntutan perkara. Adanya keenggangan anggota masyarakat jadi saksi, di samping disebabkan kesadaran hukum yang rendah juga ada faktor lain seperti kesibukan atau karena di ancam oleh tersangka. Pada kasus penebangan pohon secara illegal pelaku adalah warga setempat dan ada anggapan bagi warga lain bahwa hutan tempat mereka menebang pohon tersebut adalah kawasan hutan milik nenek moyangnya yang sudah menjadi tempat mereka bekerja dan mencari nafkah secara turun temurun. Penebangan pohon di kawasan hutan cagar alam maninjau berdasarkan jumlah kasus yang terjadi semuanya dilakukan masyarakat setempat untuk mata pencarian bukan oleh pengusaha besar untuk keperluan industri. Pada kondisi seperti ini masyarakat lain tidak mau melaporkan atau menjadi saksi pada perkara tindak pidana pencurian kayu yang terjadi. Masyarakat juga tidak mengetahui batas batas wilayah hutan cagar alam maninjau tersebut.

Yahya Harahap berpendapat bahwa lemahnya penyidik Kepolisian disebabkan oleh hal-hal antara lain jika dalam melaksanakan fungsi "control criminal" polisi terlampau keras penduduk atau masyarakat ribut dan menjerit mencemooh atmosfer kepolisian dengan tudingan bahwa kepolisian kejam. Sebaliknya jika kepolisian "gagal" mengontrol kriminal secara efektif, masyarakat yang sama "mengutuk" dan "memaki" kepolisian dengan keluhan dan keresahan bahwa kehidupan mereka "dikecam ketakutan" dan perasaan tidak aman bersamaan dengan itu, mereka menuntut peningkatan perlindugan kepolisian. Sebenarnya masih ada beberapa masalah yang timbul dan sekaligus merupakan hambatan oleh aparat penyidik yang hendak melakukan penyitaan pada tindak pidana penebangan pohon secara illegal, antara lain kekeliruan atau ketidaktanggapan ketua pengadilan negeri merespon permintaan izin penyitaan yang diminta penyidik. Memang ada indikasi, permintaan merupakan rekayasa atau 
persekongkolan antara tersangka dengan pihak ketiga untuk menghambat penyelesaian perkara pidana yang sedang ditangani pengadilan terhadap benda yang disita dalam perkara pidana tadi, sehingga cukup jelas alasan menolak pemberian izin penyitaan.

Menurut Walter C. reckless dalam berbagai sistematis penegakan hukum dan keadilan, secara teoritis menyatakan bahwa efektifitas penegakan hukum baru akan terpenuhi apabila lima pilar hukum berjalan dengan baik termasuk penegakan hukum dalam penaganan kasus illegal logging. Lima pilar tersebut yaitu:
a) Instrumen hukumnya;
b) Aparat penegak hukumnya;
c) Peralatanya;
d) Masyarakatnya;
e) Birokrasinya.

\section{PENUTUP}

Upaya Penentuan Locus Delicti Tindak Pidana penebangan pohon tanpa izin Di Kawasan Cagar Alam Maninjau Pada Tahap Penyidikan Oleh Satreskrim Polres Agam adalah untuk memenuhi unsur materil dari peraturan hukum pidana yang dilanggar. Faktor internal sebagai kendala adalah faktor Manusianya (Aparat penegak hukum) dalam hal ini penyidik Polri yang tidak memiliki keahlian khusus dalam menentukan tempat terjadinya tindak pidana penebangan liar sehingga memerlukan keterangan ahli. Adanya keenggangan anggota masyarakat jadi saksi.

\section{REFERENSI}

Haryadi Kartodiharjo, Modus Operandi, Scientific Evidence dan Legal Evidence Dalam Kasus Illegal Logging, Makalah disampaikan dalam Pelatihan Hakim Penegakan Hukum Lingkungan yang diselenggarakan oleh ICEL bekerjasama dengan Mahkamah Agung RI, Jakarta 2003

Fadli. Moh. Noch, Permasalahan Penegakan Hukum Kejahatan Kehutanan (Illegal logging) di Kalimantan Timur. Web; http://fadlimohnoch.blogspot. com/2011/02/permasalahanpenegakan-hukum-kejahatan.html

Satochid Kartanegara, Hukum Pidana,: Balai Lektur Mahasiswa, Yogyakarta, 2000

M. Yahya Harahap, Pembahasan Permasalahan Dan Penerapan KUHAP (Jilid I), Pustaka Kartini, Jakarta, 2001

P.A.F. Laminatang, Pembahasan KUHAP menurut Ilmu Pengetahuan Hukum Pidana dan Yurisprudensi, Sinar Grafika, Jakarta, 2010

Undang undang Nomor 18 Tahun 2013 tentang Pencegahan dan Pemberantasan Perusakan Hutan. 